Teologia i Moralność, Volumen 15(2020), numer 2(28)

doi: 10.14746/tim.2020.28.2.04

ORCID: 0000-0002-3382-4511

WŁADYSŁAW MAJKOWSKI

Akademia Polonijna w Częstochowie

Wyższe Seminarium Księży Sercanów w Stadnikach

\title{
Uniwersytet Trzeciego Wieku jako forma pomocy seniorom
}

\author{
„Zbliża się starość, wzgardzona, bezsilna \\ i smutna, a z nią cierpienie i ból"'
}

Sofokles

Chociaż życie ludzkie jest jednym ciągłym procesem, to jednak psychologowie i socjologowie zwykli je dzielić na kilka okresów. Najczęściej wyróżnia się ich pięć: niemowlęctwo, dziecięctwo, młodość, wiek dojrzały i starość. Każdy z tych etapów ma właściwe sobie cechy pozytywne i negatywne; prezentuje swoje możliwości i ograniczenia, radości i smutki...

Ostatnim okresem życia ogromnej większości ludzi jest starość. Podobnie jak i inne etapy życia człowieka, nie jest oddzielony od pozostałych okresów jakąś linią demarkacyjną, wyznaczającą jego początek, inaczej niż śmierć, która oddziela życie od nieżycia. Prawdą natomiast jest, że dzięki rozwojowi medycyny i lepszej opiece społecznej wydłuża się średnia ludzkiego życia, a w konsekwencji zwiększa się liczba ludzi w podeszłym wieku, ludzi starych.

Ze starością związane są wielorakie problemy, ograniczenia i trudności. Jedne $\mathrm{z}$ nich są ponadczasowe, a więc zawsze były, są i będą doświadczane przez ludzi starych. Należą do nich: choroby, niemoc, uzależnienie od innych... Inne wyrastają w ramach określonych społeczeństw, ich struktur i systemu wartości danego typu społeczeństwa... Klasycznym przykładem takiej sytuacji jest wykluczenie ludzi starszych z pewnych form życia społecznego, ich deprecjacja w kontekście zaprzestania odgrywania ról, które są podstawą społecznego prestiżu i kryterium przydatności w społeczeństwie. Następstwem takich postaw jest izolacja ludzi starych...

Nowoczesne społeczeństwo jest źródłem frustracji dla ludzi starych. Powód tego jest prosty: niegdyś, jako aktywni, przy odpowiednim wysiłku, byli 
ludźmi swej epoki. Byli przygotowani do pełnienia konkretnych funkcji i pełnienia ich $\mathrm{w}$ określony sposób. W pewnym momencie życia przestali nadążać za zmianami, zwłaszcza technologicznymi, co zaczęło ich dyskryminować wobec młodych, żyjących pełnią kultury swego czasu. Stąd jest tylko krok do osobistej frustracji, wyrastającej ze świadomości bycia dystansowanym przez młodych, ludzi nowej epoki.

Sytuacja była zgoła odmienna w społeczeństwach agrarnych, pierwotnych. W tych społecznościach ludzi starych otaczano szacunkiem z racji ich doświadczenia, którym mogli się podzielić z innymi, młodszymi. Ich doświadczenie nie podlegało erozji przez zmiany, ponieważ te zachodziły wolno. To, co było dobre dla dziadka, było dobre i dla jego syna, a nawet dla wnuka. Człowiek starszy miał więcej czasu niż człowiek młody, by zdobyć doświadczenie i umiejętności liczące się w życiu społecznym. W takiej sytuacji - zauważa św. Jan Paweł II w adhortacji Familiaris consortio - człowiek stary wypełniał „cenne posłannictwo świadka przeszłości i inspiratora mądrości dla młodych i dla przyszłości” (FC, 27).

Współcześnie wiele społeczeństw starzeje się. Proces ten ma źródło w dwóch czynnikach: obniżeniu się płodności współczesnych kobiet i wydłużeniu się życia jednostek w nowoczesnym społeczeństwie (zob. Frątczak, Jeleń-Osiecka 2015, 13-60). W takiej sytuacji poszerza się kategoria ludzi starych, którzy doświadczają problemów swojego wieku. Z tym zaś wiąże się konieczność stworzenia nowych instytucji, które zaspokajałyby potrzeby seniorów, mające źródło w deficytach związanych z zaawansowanym wiekiem. Jedną z takich instytucji wychodzącą naprzeciw potrzebom ludzi starych są Uniwersytety Trzeciego Wieku. Ich rola w tym zakresie jest przedmiotem niniejszego elaboratu.

\section{Problemy ludzi w podeszlym wieku}

Największymi problemami ludzi w podeszłym wieku są: społeczna izolacja, problemy zdrowotne, zawężanie się ich fizycznych i intelektualnych możliwości.

\subsection{Społeczna izolacja w kontekście zaprzestania odgrywania społecznych ról}

Nowoczesne społeczeństwo, zwykle kreując otwarte struktury społeczne, a zatem stwarzając szanse awansu społecznego wszystkim, w szczególności wywodzącym się z niższych klas społecznych w ramach pełnionych funk- 
cji, jednocześnie staje się czynnikiem wykluczenia dla tych, którzy przestają te role odgrywać, czyli ludzi starszych, którzy przestają być aktywni zawodowo. Ta sytuacja jest zaprzeczeniem tego, co miało miejsce w społecznościach agrarnych, kiedy status społeczny był związany z rodziną. Miał też charakter statusu przypisanego, który był udziałem jednostki na całe życie. Oznaczało to w praktyce, że nawet podeszły wiek nie był czynnikiem obniżającym ten status, wręcz nawet go podnosił, zważywszy szacunek, jakim cieszyli się ludzie starzy ze względu na doświadczenie, którym dysponowali (Majkowski 2010, 65). To ze starością wiązano rozwagę, sprawiedliwość, wstrzemięźliwość i mądrość. Zwłaszcza ta ostatnia była szczególnie ceniona, a związane z nią umiejętności nie ulegały dezaktualizacji. Odwrotnie, brak cnót, powszechnie przypisywanych seniorom, oraz zachowania negatywne ludzi starych: gwałtowność czy brak powagi i opanowania, były wyjątkowo negatywnie oceniane.

Z biegiem czasu ten pozytywny obraz człowieka starego i starości zaczął się radykalnie zmieniać. Punktem odniesienia oceny ludzi starych stała się ich społeczna nieaktywność. W sytuacji, kiedy podstawą społecznej stratyfikacji są odgrywane przez jednostkę role społeczne, promocja ludzi młodych, aktywnych na różnych polach staje się oczywista. Odwrotnie - ludzie starzy, którzy przestali pełnić społeczne funkcje, w szczególności zawodowe, tracą związaną z ich pełnieniem społeczną pozycję. Jednostka, która nie odgrywa ważnych społecznie ról, jest degradowana w społecznej hierarchii. W takiej sytuacji „osoby dotychczas aktywne zawodowo stają się zawodowo bierne, producenci - dawcy przemieniają się w biorących. W rodzinie do niedawna żywiciele, opiekunowie i wychowawcy swych dzieci, obdarzeni autorytetem, sami zaczynają potrzebować pomocy i opieki [...]. Następuje więc swoiste odwrócenie ról” (Piotrowski 1973, 25). W konsekwencji ludzie tej kategorii są traktowani jako społecznie niepotrzebni. Gdy do tego dołączy się koszty, jakie generują ze względu na wielorakie deficyty, przypisanie im etykiety ,pasożytów" jest wielce prawdopodobne.

Człowiek w podeszłym wieku (emeryt, ale również rencista), przestając pracować zawodowo, przestaje pełnić funkcje, które są źródłem społecznego statusu. Ludzie tacy przestają być społecznie potrzebni, a w konsekwencji są izolowani i popadają $\mathrm{w}$ osamotnienie; zostają zepchnięci na margines społecznego życia (FC, 27). Tu właśnie ma swoje źródło dylemat, przed którym stają jednostki przed emeryturą: pracować dalej zawodowo czy zrezygnować z pracy. W pierwszym przypadku jednostka zachowuje swoją pozycję społeczną, ale musi odgrywać uciążliwe role, podejmuje zobowiązania; w drugim - jest wolna od zobowiązań, ale traci swój status i społecznie jest degradowana. Dla większości ludzi starych jest to bolesny dylemat, zwłaszcza, gdy nie mają pomysłu, jak zagospodarować swój wolny czas. Jeszcze kilka lat temu w Polsce 
instytucja babci czy dziadka opiekujących się wnuczkami była często wyjściem dla starego człowieka, dając mu poczucie, że jest społecznie pożyteczny.

\subsection{Pogorszenie się zdrowia i ograniczenie możliwości ludzi starych}

Wielkim problemem ludzi starych jest kwestia pogarszania się ich ogólnego stanu zdrowia. Słabnące zdrowie jest więc ciężkim brzemieniem ludzi starych. Wynikające ze starości zmiany w różnych częściach organizmu sprawiają im często ból i cierpienie. Najczęstszymi dolegliwościami tego okresu są: bóle i zawroty głowy, reumatyzm, bezsenność, trudności w poruszaniu się, amnezja, problemy systemu trawiennego i wydalniczego, niewydolność serca, nadciśnienie, choroby nerek, niewydolność płuc, osłabienie wzroku i słuchu...

Chorobą, która w podeszłym wieku w szczególny sposób degraduje fizycznie jednostkę, jest miażdżyca. Odkładające się złogi cholesterolu i wapnia w wewnętrznej części tętnic powodują pogorszenie ukrwienia ważnych dla życia narządów, co w następstwie pociąga za sobą ich niewydolność i ciężkie powikłania: zawał serca, udar mózgu, zgorzel...

Drugą ogromnie upokarzającą dolegliwością człowieka starego jest zanik sprawności narządów ruchu. Bóle reumatyczne utrudniają mu poruszanie się, a choroba gośćcowa prowadzi do zwyrodnienia stawów, co wcześniej czy później kończy się przykuciem chorego do wózka inwalidzkiego.

\subsection{Ograniczone możliwości somatyczne}

Zważywszy osłabienie organizmu człowieka starego, wynikające z niewydolności różnych jego organów, człowiek stary doświadcza swojej niemocy. Jest to przede wszystkim niemoc fizyczna. Brak fizycznej siły najpierw do cięższych prac, a później nawet do lekkich zajęć, daje mu poczucie niemocy, niepewności, zależności od innych... Zaś przywoływanie w pamięci czasów fizycznej sprawności nie tylko nie daje mu satysfakcji, a wręcz wzmaga świadomość przemijania... To zawężenie możliwości wyraził w poetycki, a jednocześnie dobitny sposób, Krzysztof Kamil Baczyński:

Otom tak w drodze długiej zmalał, Że sam ledwo widzę swoją postać (Baczyński 1941).

Ograniczone fizyczne możliwości zawężają przestrzeń człowieka starego, coraz bardziej ograniczając świat jego fizycznych odniesień. Najpierw jest to najbliższe jego otoczenie (sąsiedztwo), później własny dom, a w końcu pokój 
i... łóżko. Z taką sytuacją wiąże się zawsze samotność jako wynik ograniczenia pola odniesień do innych, w następstwie czego stary człowiek doznaje poczucia osamotnienia. To ostatnie jest subiektywnym sposobem przeżywania samotności w kontekście osobistych doświadczeń, wrażliwości, stanu zdrowia, wiary w Boga, czasu pojawienia się deficytów... Oznacza to, że „można być samotnym i osamotnionym, ale można też żyć samotnie i nie odczuwać osamotnienia - mieć w pełni zaspokojone potrzeby społecznej użyteczności, akceptacji, partycypacji, aktywności” (Trafiałek 2016, 147).

Największym jednak problemem starości jest osłabienie sprawności umysłowej jednostki. Wyraża się to w zaniku pamięci, osłabieniu stopnia orientacji przestrzennej i społecznej, osłabieniu krytycyzmu względem samego siebie i obiektywnej oceny rzeczywistości, wzmożonych oczekiwań względem innych na bazie faktycznych czy wyimaginowanych swoich zasług... Zaawansowany stan osłabienia sprawności umysłowej prowadzi do sytuacji, w której człowiek nie radzi sobie z najprostszymi problemami, chociaż usilnie stara się je rozwiązywać. To z kolei jest dla człowieka starego powodem zniecierpliwienia, irytacji, zdenerwowania na siebie, najbliższych i całe otoczenie.

\section{Uniwersytet Trzeciego Wieku jako forma pomocy seniorom}

Wymienione wyżej problemy seniorów są po części związane z obiektywnymi ograniczeniami wieku senioralnego, a po części z funkcjonowaniem nowoczesnego społeczeństwa. Ani jedne, ani drugie nie mogą być całkowicie wyeliminowane, ponieważ wyrastają na kanwie obiektywnego stanu rzeczy, jakim jest starość. Jednak ostrze negatywnych doświadczeń może być znacząco mitygowane. Nie ma też jednej recepty na przeżywanie starości, dlatego że każdy człowiek przeżywa ją na własny sposób w zależności od osobistej kondycji i okoliczności, w jakich się znajduje. Jest także wiele instytucji, które wychodzą naprzeciw potrzebom ludzi starszych: rodzina, kluby seniorów, organizacje o charakterze religijnym czy Uniwersytet Trzeciego Wieku. Rolę tego ostatniego, w kontekście starości, pragnę tu naświetlić.

\subsection{Początki Uniwersytetów Trzeciego Wieku}

Idea Uniwersytetów Trzeciego Wieku zrodziła się w drugiej połowie XX wieku we Francji. Inicjatorem pierwszego Uniwersytetu Trzeciego Wieku był prof. Pierre Vellas, który zgromadził na Uniwersytecie w Tuluzie grupę seniorów, by się od nich dowiedzieć, czego oczekiwaliby od ich instytucji. $Z$ badania wynikało, że oczekiwania te koncentrowały się wokół trzech problemów: 
upowszechnienia wiedzy na temat starości, a szczególnie na temat zdrowia ludzi starych; rozwiązywania problemów, z jakimi borykają się ludzie starzy, oraz włączenia doświadczenia ludzi starych do nowych trendów kulturowych. Tak zarysowany cel Uniwersytetów Trzeciego Wieku okazał się zbyt zawężony, w miarę jak do tej instytucji wchodzili ludzie należący do różnych kategorii zdrowotnych i edukacyjnych oraz osoby o różnych możliwościach intelektualnych. Zaistniała zatem konieczność poszerzenia kategorii słuchaczy Uniwersytetów Trzeciego Wieku zgodnie z ich sytuacją i oczekiwaniami. Również sama idea tej formy aktywności seniorów została entuzjastycznie przyjęta, co dało początek wielu tym instytucjom w różnych państwach. Poszczególne ośrodki także modyfikowały tak program Uniwersytetów Trzeciego Wie$\mathrm{ku}$, jak i sposoby ich funkcjonowania. Chociaż początkowo instytucje te były powiązane $\mathrm{z}$ uczelniami, to jednak były też organizowane $\mathrm{w}$ innych formach. I tak w Stanach Zjednoczonych z inicjatywy Martina Knowltona powstał Uniwersytet Trzeciego Wieku na wzór młodzieżowego schroniska, którego program był zwykle realizowany w miesiącach wakacyjnych. Jego atrakcyjność wyrastała w kontekście powiązania szkolenia z urlopem. Tym sposobem w ramach jednego programu były łączone różne funkcje tej instytucji.

Idea Uniwersytetu Trzeciego Wieku została przeniesiona na grunt polski przez prof. Halinę Schwarz, która przy wsparciu prof. Pierre'a Vellas'a utworzyła taki Uniwersytet w Warszawie w 1975 roku, nadając mu nazwę Studium III Wieku. Cele tej instytucji były zbliżone do tych, które wytyczył swojemu uniwersytetowi Pierre Vellas: objęcie seniorów systemem kształcenia ciągłego; aktywizacja seniorów we wszystkich wymiarach (fizycznym, intelektualnym i psychicznym) oraz studium problematyki gerontologicznej (Jachimowicz, Nalepa 2012, 7).

Chociaż tworzenie Uniwersytetów Trzeciego Wieku w Polsce spotkało się z wielkim zainteresowaniem tak instytucji, przy których były one zakładane, jak i samych seniorów, to jednak po okresie ich intensywnego rozwoju w latach 1975-1979 nastąpiło okresowe spowolnienie w ich zakładaniu. Dopiero po roku 1989 ponownie zaczęto tworzyć ich tak wiele, że obecnie nie tylko prawie wszystkie wyższe szkoły prowadzą tę działalność, ale i inne ośrodki edukacyjne i kulturalne, niektóre stowarzyszenia czy podmioty prowadzące działalność w strukturach jednostek samorządu lokalnego.

Tym sposobem liczba Uniwersytetów Trzeciego Wieku obecnie wynosi 500. By nadać rangę tej działalności, Senat Rzeczypospolitej ustanowił rok 2012 Rokiem Uniwersytetów Trzeciego Wieku, a w ramach jego obchodów 19-20 marca w Warszawie odbył się Kongres Uniwersytetów Trzeciego Wieku. 


\subsection{Najważniejsze cele Uniwersytetu Trzeciego Wieku}

Cele Uniwersytetu Trzeciego Wieku są ściśle powiązane z deficytami i potrzebami seniorów. Rzecz bowiem w tym, że starość ze swoimi ograniczeniami nakłada na seniorów wielorakie ograniczenia, a w konsekwencji prowadzi do ich marginalizacji w życiu społecznym. Dotyczą one prawie wszystkich aspektów ich życia, poczynając od somatycznych ograniczeń, a na intelektualnych kończąc. Wszystkie zatem inicjatywy, które przeciwdziałają wykluczeniom ludzi starych czy też przedłużają ich sprawność w jakiejkolwiek dziedzinie, stają się ze wszech miar pożądane i mogą stanowić cel Uniwersytetu Trzeciego Wieku (Chabior 2014, 307-309). Oto najważniejsze z nich.

\subsubsection{Antidotum na osamotnienie}

Jeśli jest prawdą, że starość zawęża kontakty z innymi, najpierw zawodowe, a następnie nawet sąsiedzkie, to uczestnictwo w programach Uniwersytetu Trzeciego Wieku stwarza nową ich formę. Najpierw samo spotkanie się z innymi uczestnikami programu Uniwersytetu Trzeciego Wieku wyrywa jednostkę z marazmu osamotnienia. I chociaż jest to spotkanie mocno ograniczone w czasie, to jednak wpływa pozytywnie na psychikę osoby starszej. Niektóre jednostki już znacznie wcześniej przygotowują się do tego spotkania, myślą o nim i go wyczekują (por. Konieczna-Woźniak 2001, 155).

Częścią składową tego antidotum na osamotnienie jest nawiązywanie nowych relacji z innymi uczestnikami programu. Zadanie jest tym łatwiejsze, że jego uczestnicy są w podobnej sytuacji - ludzi zawodowo nieaktywnych, a ich przeszłe doświadczenia, podzielane z innymi, stanowią płaszczyznę nowej interakcji. Jest to ogromnie ważne z tej racji, że ludzie starsi, nawet dobrze wykształceni, nie nadążają za zmianami, jakie zachodzą w nowoczesnym świecie. Dotyczy to nade wszystko zmian w świecie technologii, środków komunikacji, ale też i nowych metod w świecie nauki. Obydwa typy zmian stwarzają poczucie alienacji. Nowa technologia jest obca dla ludzi starszych, a oni sami już w tym nowym świecie nie odnajdują się; nie inaczej jest z postępem nauki. Młodsze pokolenie dystansuje ich w tym świecie. Stąd platformą spotkania staje się wspólnota trzeciego wieku.

\subsubsection{Przedłużenie sprawności intelektualnej}

Chociaż człowiek w pewnym sensie uczy się przez całe swoje życie, to wiedzę zdobywa zasadniczo w pierwszym okresie swojego istnienia. Niewie- 
lu jest ludzi, którzy w podeszłym wieku zdobywają naukowe szlify. Trzeci wiek jest okresem zaniżonej percepcji, a więc bardziej pożytkowania wcześniej zdobytych kompetencji. W tym zakresie ludzie starsi nawet przewyższają młodsze pokolenie. Dobrze orientują się w minionym świecie, ale zdobywanie nowych umiejętności staje się dla nich problemem. Każda forma treningu zmierzająca do podtrzymania zdolności intelektualnych, a w szczególności percepcji nowych treści, jest dla nich wartością nie do przecenienia - przedłuża ich intelektualny potencjał. Nie dziwi zatem fakt, że z badań wynika, iż jest to najczęstszy motyw uczestniczenia w programie Uniwersytetu Trzeciego Wieku - blisko 82\% (Wróblewska, Błaszczuk 2012, 32). Spotkania na Uniwersytecie, a w szczególności nowe podejście do problemów, jest inspiracją i odkrywaniem świata, który obecnie istnieje (por. Konieczna-Woźniak 2011, 111-123).

\subsubsection{Kursy, szkolenia}

Ważnymi elementami programu Uniwersytetów Trzeciego Wieku są kursy i szkolenia. Jest tak niezależnie od faktu, że zdobywane tu umiejętności zasadniczo nie będą wykorzystywane przez uczestników w pracy zawodowej, ponieważ zawodowo są nieaktywni. Zdobyte umiejętności mają zasadniczo inne zadanie. Pierwszym jest rodzaj updatingu - doszlusowania do zmian, jakie zaszły na polu ich zainteresowań, a w szczególności w zakresie narzędzi i programów. Nie dziwi zatem, że w programie Uniwersytetów Trzeciego Wieku prawie zawsze są zajęcia komputerowe czy analiza nowych problemów społeczno-kulturowych. Pierwsze mają oswoić uczestników z nowymi możliwościami technicznymi; drugie - z zachodzącymi w społeczeństwie procesami i zmianami. Obydwie te funkcje wpisują się bardzo dobrze w to, czego bezpośrednio czy pośrednio oczekują seniorzy.

\subsubsection{Zajęcia ruchowe, rehabilitacyjne, rekreacyjne}

Bolesnym doświadczeniem ludzi starych są fizyczne ograniczenia, przejawiające się najczęściej w trudnościach ruchowych. Wszelkie zatem działania, które podtrzymują zdolności ruchowe, czy wręcz je przywracają, są wyjątkowo im potrzebne i stają się zwykle częścią programu Uniwersytetu Trzeciego Wieku. Pierwsze mają na celu spowolnienie procesu ograniczeń ruchowych ludzi starych, drugie (rehabilitacyjne) są ukierunkowane na przywrócenie utraconych zdolności ruchowych. Forma tego rodzaju zajęć jest oczywiście uzależniona od stanu zdrowia uczestników kursu. 


\subsubsection{Imprezy kulturalne, turystyczne}

Ważną częścią programu Uniwersytetu Trzeciego Wieku są imprezy o charakterze kulturalnym. Zwykle są dwie możliwe formy uczestnictwa $\mathrm{w}$ tym programie: uczestnictwo bierne i uczestnictwo czynne. W pierwszej formie partycypacji w programie uczestnicy Uniwersytetu Trzeciego Wieku są raczej odbiorcami, obserwatorami organizowanej dla nich imprezy; w drugim sami stają się aktorami imprez. Pierwsze mają na celu nade wszystko miłe spędzenie wolnego czasu; drugie dodatkowo aktywizują seniorów. Polem tej aktywizacji jest zarówno sprawność ruchowa, jak i percepcja intelektualna. Najczęstszą formą takiej aktywizacji jest chór czy kółka aktorskie (Litawa 2011, 126). Obydwie bazują na pewnych uzdolnieniach artystycznych seniorów, które wcześniej nie miały możliwości się rozwinąć albo teraz są podtrzymywane dla własnej satysfakcji i pożytku innych. Funkcje pełnione przez ten rodzaj aktywności są wielorakie: rekreacyjna, ekspresywna, edukacyjna, a nawet kulturotwórcza.

Ważną częścią programu Uniwersytetu Trzeciego Wieku są imprezy o charakterze turystycznym (Grotowska 2011, 186-196). Seniorzy bardzo chętnie uczestniczą w tego rodzaju programach. Dotyczy to tak miejsc, które są im znane z lat wcześniejszych, jak i nowych atrakcji turystycznych. Jak ważny to jest element programu Uniwersytetu Trzeciego Wieku, niech świadczy to, że seniorzy nawet od rodziny oczekują podobnych inicjatyw ${ }^{1}$. Tego rodzaju oczekiwania w stosunku do różnych podmiotów wyrastają w kontekście ograniczeń ruchowych seniorów. Jeśli w drobniejszych sprawach zachowali jeszcze znaczną dozę samowystarczalności, to w tym zakresie są już całkowicie zdani na pomoc innych.

\section{Czy starość musi być dramatem?}

Biorąc pod uwagę wspomniane wyżej ograniczenia, choroby i izolację człowieka starego, rodzi się pytanie: Czy starość koniecznie musi być dramatem? Czy jest sposób, by uczynić z niej pogodną jesień życia? W mojej ocenie, jest to możliwe pod dwoma warunkami: po pierwsze, człowiek stary nie może stracić nadziei, po drugie, musi patrzeć na życie w perspektywie wiary.

${ }^{1} \mathrm{Z}$ badań wynika, że prawie $54 \%$ seniorów oczekuje od swojej rodziny pomocy w zakresie wycieczkowym. (por. Cherchowska 2015, 79). 


\subsection{Nadzieja}

Jeśli jest prawdą, że nadzieja i zawierzenie potrzebne są każdemu człowiekowi, by nie dostrzegać swoich słabości i małostkowości, mierzyć siły na zamiary, podejmować trudne działania, kontynuować beznadziejne walki..., to tym bardziej są potrzebne człowiekowi staremu, by wierzyć, że życie pełne słabości, ograniczeń i bólu ma sens! W miarę zbliżania się do starości, bezsiły, ograniczeń... potrzebna jest człowiekowi nadzieja, że jakoś się ułoży, że będzie mógł żyć, że nawet może być lepiej. Taka nadzieja sprawi, że człowiek stary będzie bronił się przed myślą o starości i jej problemach, zbliżającej się bezsile, niedołężności..., będzie wierzył, że „nie przyjmując do wiadomości” stających się jego udziałem problemów, sprawi, że rzeczywistość „dostosuje” się do jego nadziei. Nadzieja mająca swą podstawę w rzeczy, a nawet nadzieja wbrew nadziei, jest dla człowieka starego konieczną postawą, by nie załamał się psychicznie i by nie ogarnęła go rozpacz. W jego sytuacji brak nadziei byłby przedsionkiem śmierci najpierw w wymiarze psychicznym, a następnie fizycznym. Stąd ,nawet jeżeli nadzieja ma swoje irracjonalne przejawy, to przecież jest w niej także element przekonania, że przebieg spraw jest prawidłowy, tzn. kierowany prawami, i że ten przebieg, na który z nadzieją liczymy, ułoży się według praw dla nas pomyślnych... Bez nadziei nie ma więc dążenia do celu, nawet najbardziej racjonalnie przygotowanego" (Szczepański 1988, 273).

\subsection{Ewangeliczna perspektywa}

Skoro nierzadko zdarza się, że młody i zdrowy człowiek stawia sobie pytanie o sens swojego życia, to takie pytanie musi się także jawić człowiekowi staremu. Jeśli młody i zdrowy człowiek nie znajduje pozytywnej odpowiedzi w tym zakresie, czego wyrazem bywa niekiedy akt samobójczy, to tym bardziej nieuniknione jest pytanie o sens życia, jakie jawi się w tym zakresie człowiekowi staremu. Stary człowiek musi nie tylko dostrzegać sens swego życia w ogóle, ale gwałtownie potrzebuje odnajdywania sensu życia, które obecnie zmierza ku swemu końcowi. Nowa perspektywa musi uwzględniać w sobie, poza przemijaniem i ograniczeniami, śmierć. I chociaż niektóre systemy filozoficzne starają się stępić ostrze śmierci, to sensu ludzkiego życia, kończącego się śmiercią, nie można odnaleźć poza perspektywą wiary. Wiara, nadając sens śmierci, nadaje tym samym sens ludzkiemu życiu, które nieuchronnie zmierza do tego finalnego momentu. Podkreśla to dobitnie św. Jan Paweł II w liście do ludzi w podeszłym wieku: „wiara rozjaśnia [...] tajemnicę śmierci i opromienia swym światłem starość, która nie jest już postrzegana i przeżywana jako bierne oczekiwanie na moment unicestwienia, ale jako zapowiedź rychłego już 
osiągnięcia pełnej dojrzałości” (Jan Paweł II 1999). Wiara, stwarzając nową, ubogaconą o zwycięstwo nad śmiercią perspektywę na życie człowieka, zmienia radykalnie sens ludzkiej śmierci. W tej perspektywie nic, łącznie z ograniczeniami, cierpieniem i śmiercią, nie jest absurdem, a wręcz nabiera pozytywnego wymiaru. W perspektywie katolickiej wiary ludzka niemoc, ograniczenia i cierpienie nabierają sensu, stając się swoistym typem „aktywności” człowieka: passio summa actio est ${ }^{2}$. Cierpiący chrześcijanin - jak podkreśla papież św. Jan Paweł II w liście Salvifici doloris ,nie tylko [...] jest pożyteczny dla drugich, ale co więcej - spełnia służbę niczym niezastąpioną” (SD, 27).

Takie rozumienie starości i związanego z nim cierpienia, nie jest rodzajem jego negacji i spychania go do podświadomości. Nie jest też formą wynikającej z bezsilności arogancji, ale akceptacją trudnej rzeczywistości, którą chrześcijanin przyjmuje $\mathrm{w}$ nadziei, że doświadczenie nie przerasta jego moralnej siły. „Czyniąc to - mówi papież we wspomnianym liście - człowiek wyzwala nadzieję, która podtrzymuje w nim przeświadczenie, że cierpienie go nie przemoże, nie pozbawi właściwej człowiekowi godności wraz z poczuciem sensu życia, [...], znajduje jakby nową miarę swego życia i powołania” (SD, 23).

\section{Zakończenie}

Problemy ludzi starych są wielorakie. Wszystkie jednak mają swoje bezpośrednie czy pośrednie odniesienie do przemijania i powolnego „odchodzenia” człowieka starego. Świat człowieka, w miarę jego starzenia się, ulega powolnemu zawężeniu. Nade wszystko redukcji ulega jego siatka odniesień, relacji z innymi. Najpierw w chwili jego przejścia na emeryturę, kiedy przestaje być czynny zawodowo, a następnie w ramach jego postępujących ograniczeń wyrastających w kontekście ubytku sił fizycznych, intelektualnych możliwości czy osłabienia psychiki.

Te ograniczenia są naturalnym źródłem wykluczenia ludzi starych i do końca tego procesu nie da się zatrzymać. Jednak - jak zauważa papież Franciszek w encyklice Fratelli tutti - ,izolowanie osób starszych i pozostawienie ich pod opieką obcych, bez właściwego i bliskiego towarzyszenia rodziny, okalecza i zuboża samą rodzinę. Co więcej doprowadza do pozbawienia ludzi młodych niezbędnego kontaktu z ich korzeniami i mądrością, której młodzież nie może osiągnąć o własnych siłach” (FT, 19).

Wszelkie inicjatywy zmierzające do zminimalizowania negatywnych wymiarów starości są funkcjonalne i pożądane. Dotyczy to tak zdrowia fizycznego, psychicznego, jak i wymiaru interakcji z innymi. To jest racja, dla której

\footnotetext{
${ }^{2}$ Cierpienie jest najwyższą formą aktywności.
} 
Uniwersytety Trzeciego Wieku mają wielką rolę do odegrania, wychodząc naprzeciw potrzebom ludzi starszych. Jednak niezależnie od potrzeby tych inicjatyw na rzecz seniorów, oczywisty staje się fakt, że żadna z nich nie wyeliminuje niedogodności wieku starczego. Pogorszenie się zdrowia fizycznego, osłabienie intelektualnych możliwości, choroby, są nieodłącznie związane ze starością; są elementem „kodu genetycznego” starości. Dlatego pogodne przeżywanie deficytów starości musi mieć odniesienie do innego niż czysto naturalnego wymiaru. To ,życie ludzi starszych - jak zauważają ojcowie Soboru Watykańskiego II w Konstytucji duszpasterskiej o Kościele w świecie współczesnym Gaudium et spes - ułatwia nam zdanie sobie sprawy z hierarchii wartości ludzkich; ukazuje ciągłość pokoleń i wspaniale przedstawia wzajemną zależność Ludu Bożego" (KDK, 48). Chodzi zatem o wymiar religijny, który jako jedyny jest w stanie nadać ludzkiej starości i ludzkiej śmierci sens. Tylko religia, głosząc prawdę o życiu poza granicą śmierci, jest w stanie nadać sens ludzkiej egzystencji, pełnej ograniczeń i deficytów. O taką perspektywę starości apelował papież Franciszek w adhortacji apostolskiej Christus vivit „Wyobrażam sobie ludzi starszych jako stale obecny chór w wielkiej duchowej świątyni, w której modlitwy błagalne i pieśni chwały wspierają całą wspólnotę trudzącą się i zmagającą się na niwie życia” (ChV, 196).

\section{UNIVERSITY OF THE THIRD AGE AS A FORM OF HELP FOR SENIORS}

\section{Abstract}

The last period of life of the vast majority of people is old age. Old age is associated with multiple problems, limitations and difficulties. Some of these problems are timeless, so they have always been, and will be experienced by elderly people. These include: illness, solitude, exclusion, limitations ... Others arise within concrete forms of societies, their structures and the their value systems... A typical example of such a situation is the exclusion of elderly people from certain forms of social life, due to their retirement. Being retired they do not paly social roles that are the basis of social prestige and the criterion of suitability in society. The consequence of such situation is social isolation of old people.

Any initiative to minimize the negative features of old age is functional and desirable. This applies to both physical and mental health as well as to social interaction with others. This is the reason why Universities of the Third Age have a great role to play in meeting the needs of elderly people. However, regardless of the need for these initiatives for the benefit of seniors, it is obvious that none of them will eliminate all inconveniences of old age. Deterioration of physical health, weakening of intellectual abilities, diseases are inherent to old age; they are part of the "genetic code" of old 
age. Therefore, the serene survival of old-age deficits must be referred to a different than purely natural perspective. It is a religious view that is the only one able to give full meaning to old age and human death. Only religion, proclaiming the truth of life beyond the boundary of death, is able to give meaning to human life, full of limitations and deficits.

Keywords: old age; problems of old people; help of elderly people; Universities of the Third Age

Słowa kluczowe: starość; problemy osób starszych; pomoc osób starszych; Uniwersytety Trzeciego Wieku

\section{BIBLIOGRAFIA}

Baczyński, Krzysztof Kamil. 1941. Starość. Dostęp: 10.07.2020. wolnelektury.pl/media/book/pdf/ baczynski-starosc.pdf

Chabior, Agata. 2014. Społeczne, kulturowe i demograficzne uwarunkowania opieki i wsparcia w starości. O nowy model opiekuna seniorów. W: Innowacje w polityce społecznej XXI wieku, red. Elżbieta Trafiałek. 305-314. Katowice: Uniwersytet Jana Kochanowskiego.

Cherchowska, Justyna. 2015. Rola rodziny w aktywizacji rekreacyjnej seniorów. W: Rodzina wobec problemów $i$ wyzwań wspótczesności. W poszukiwaniu rozwiązań, red. Bożena Chrostowska, Magdalena Dymowska i Magdalena Zmysłowska. Tom 2. 71-83. Olsztyn: Wydawnictwo Uniwersytetu Warmińsko-Mazurskiego.

Franciszek. 2019. Christus vivit.

Franciszek. 2020. Fratelli tutti.

Frątczak, Ewa. Jeleń-Osiecka, Monika. 2015. Przemiany płodności - intencje rodzicielskie - relacje międzygeneracyjne w Polsce. W: Rodzina dobro zagrożone, red. Władysław Majkowski. 13-60. Kraków: Wydawnictwo Księży Sercanów.

Grotowska, Stella. 2011. Seniorzy w przestrzeni publicznej. Kapitat spoleczny uczestników wspólnot, ruchów i stowarzyszeń katolickich. Kraków: Zakład Wydawniczy „Nomos”.

Jan Paweł II. 1983. Familiaris consortio.

Jan Paweł II. 1984. Salvifici doloris.

Jan Paweł II. 1999. Do moich sióstr i braci-ludzi w podesztym wieku.

Konieczna-Woźniak, Renata. 2001. Uniwersytety Trzeciego Wieku w Polsce. Profilaktyczne aspekty edukacji seniorów. Poznań: „Eruditus”.

Konieczna-Woźniak, Renata. 2011. Uczenie się ludzi dorosłych poprzez ich zainteresowania wolnoczasowe. Edukacja Dorostych, 2, 65, 111-124.

Litawa, Aleksandra. 2011. Chór amatorski jako przestrzeń uczenia się ludzi dorosłych. Edukacja Dorostych, 2, 65, 125-135.

Majkowski, Władysław. 2010. Rodzina polska w kontekście nowych uwarunkowań. Kraków: Wydawnictwo Księży Sercanów.

Piotrowski, Jerzy. 1973. Miejsce człowieka starego w rodzinie i spoleczeństwie. Warszawa: Państwowe Wydawnictwo Naukowe.

Sobór Watykański II. 1965. Konstytucja duszpasterska o Kościele w świecie współczesnym „Gaudium et spes".

Szczepański, Jan. 1988. Sprawy ludzkie. Warszawa: Czytelnik.

Trafiałek, Elżbieta. 2016. Innowacyjna polityka senioralna XXI wieku. Między ageizmem, bezpieczeństwem socjalnym i active ageing. Toruń: Wydawnictwo Adam Marszałek. 
Wróblewska, Izabela. Błaszczuk, Jerzy. 2012. Uniwersytet Trzeciego Wieku jako instytucja aktywizująca osoby starsze. Badania własne. Nowiny Lekarskie, 81, 31-35.

WŁadySŁaw MAJKowski - ks. prof. dr hab., był wieloletnim wykładowcą socjologii ogólnej, historii myśli społecznej, socjologii rodziny oraz problemów współczesnej rodziny polskiej najpierw w Akademii Teologii Katolickiej, a następnie na Uniwersytecie Kardynała Stefana Wyszyńskiego w Warszawie; obecnie jest też wykładowcą socjologii i katolickiej nauki społecznej w Wyższym Seminarium Misyjnym Księży Sercanów w Stadnikach oraz wykładowcą w Akademii Polonijnej w Częstochowie. Przedmiotem jego zainteresowań naukowych są: społeczna stratyfikacja, społeczna dewiacja, socjologia rodziny, historia myśli społecznej oraz problemy i patologie życia społecznego, a w szczególności rodziny. Ksiądz W. Majkowski jest autorem książek oraz ponad stu artykułów w języku polskim, włoskim i angielskim. 